\title{
Article
}

\section{The role of governance in mobile phones for inclusive human development in Sub- Saharan Africa}

Asongu, Simplice A. and Nwachukwu, Jacinta Chikaodi

Available at http://clok.uclan.ac.uk/24921/

Asongu, Simplice A. and Nwachukwu, Jacinta Chikaodi ORCID: 0000-00032987-9242 (2016) The role of governance in mobile phones for inclusive human development in Sub-Saharan Africa. Technovation, 55-56 . pp. 1-13. ISSN 0166-4972

It is advisable to refer to the publisher's version if you intend to cite from the work. http://dx.doi.org/10.1016/j.technovation.2016.04.002

For more information about UCLan's research in this area go to http://www.uclan.ac.uk/researchgroups/ and search for <name of research Group>.

For information about Research generally at UCLan please go to http://www.uclan.ac.uk/research/

All outputs in CLoK are protected by Intellectual Property Rights law, including Copyright law. Copyright, IPR and Moral Rights for the works on this site are retained by the individual authors and/or other copyright owners. Terms and conditions for use of this material are defined in the policies page.

\section{CLoK}

Central Lancashire online Knowledge www.clok.uclan.ac.uk

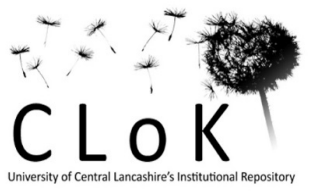




\title{
A G D I Working Paper
}

\section{WP/16/007}

\section{The Role of Governance in Mobile Phones for Inclusive Human Development in Sub-Saharan Africa}

\author{
Simplice A. Asongu \\ African Governance and Development Institute, \\ P.O. Box 8413 Yaoundé, Cameroon. \\ E-mail: asongusimplice@yahoo.com /asongus@afridev.org \\ Jacinta C. Nwachukwu \\ School of Economics, Finance and Accounting, \\ Faculty of Business and Law, \\ Coventry University \\ Priory Street, Coventry, CV1 5FB, UK \\ Email: jacinta.nwachukwu@ coventry.ac.uk
}

Forthcoming: Technovation 


\title{
AGDI Working Paper
}

Research Department

\section{The Role of Governance in Mobile Phones for Inclusive Human Development in Sub-Saharan Africa}

\section{Simplice A. Asongu \& Jacinta C. Nwachukwu}

January 2016

\begin{abstract}
This study assesses the synergy effects of governance in mobile phone penetration for inclusive human development in Sub-Saharan Africa with data for the period 2000-2012 by employing a battery of interactive estimation techniques, namely: Fixed effects (FE), Generalised Method of Moments (GMM) and Tobit regressions. Concepts of political (voice $\&$ accountability and political stability/no violence), economic (government effectiveness and regulation quality) and institutional (corruption-control and rule of law) governance are employed. The following findings are established. First, the previously apparent positive correlation between mobile phones and inclusive development can be extended to a positive effect. Second, whereas political governance is overwhelmingly not significant across estimated models, average effects from economic governance are higher relative to institutional governance. Third, on the synergy effects from interactions between mobile phones and governance variables, whereas none are apparent in FE regressions, there are significant synergy effects in GMM and Tobit estimations, notably, from: (i) regulation quality in the former and (ii) political stability, voice \& accountability and rule of law in the latter. Fourth, there is consistent evidence of convergence in inclusive human development. Policy implications are discussed.
\end{abstract}

JEL Classification: G20; I10; I32; O40; P37

Keywords: Mobile phones; governance; inclusive human development 


\section{Introduction}

There are at least four reasons for investigating the synergy effects of governance in mobile phone penetration for inclusive human development in Sub-Saharan Africa (SSA). The terms, 'mobile phone penetration', 'mobile telephony', 'mobile' and 'mobile phones' are used interchangeably throughout the paper. First, the April 2015 World Bank report on attainment of the Millennium Development Goal (MDG) extreme poverty target has revealed that poverty has been decreasing in all regions of the world with the exception of SSA (World Bank, 2015; Asongu \& Kodila-Tedika, 2015).

Second, whereas high-end markets in North America, Europe and Asia are experiencing some degree of stabilization in the growth of mobile phones, there are still substantial business opportunities in developing African markets (Asongu, 2015a). Moreover, according to Penard et al. (2012), Africa has been experiencing an uneven development in mobile phone versus internet penetration. Consistent with the account, as of 2010, mobile and internet penetrations had reached saturation points in developed countries, whereas in Africa the phenomena have been characterised by an asymmetric development, notably: with $41 \%$ of mobile phone penetration and $9.6 \%$ of internet penetration.

Third, government quality has been substantially documented to be associated with higher living standards, notably, in the: (i) improvement of quality of life by more efficient allocation of economic resources (Fosu, 2013ab; Anyanwu \& Erhijakpor 2014), especially for the elderly that are deprived (Fonchingong 2014) and (ii) consolidation of a solid foundation for societal change (Efobi, 2015). In essence, exclusive growth in Africa and the role of institutions in Africa's growth resurgence have motivated a recent book by Fosu (2015ab) that is focused on assessing whether the recent growth resurgence experienced by the continent from the mid-1990s (Fosu, 2015c, p. 44) is a myth. The notion of myth in the book fundamentally builds on the fact that the juice of economic prosperity has not been trickling down to the poor. We aim to extend this strand of literature by examining the synergy effects of governance in mobile phones for inclusive development in a SSA: a sub-region with $45 \%$ of countries off-track from the MDG extreme poverty target.

Fourth, mobile phones in Africa have been established to: (i) be more associated with the informal economic sector, as opposed to its formal component (Asongu, 2013a) and (ii) mitigate income-inequality (Asongu, 2015b). This is consistent with the growing literature on inclusive development benefits from mobile phones, inter alia, for the: (i) empowerment of women (Ojo et al., 2012; Maurer, 2008); (ii) promotion of financial inclusion (Singh, 2012, p. 
466; Kirui et al. 2013, p. 141); (iii) improvement of health services for the poor (Kliner et al., 2013); (iv) bridging of the rural-urban divide (Chan \& Jia, 2011, pp. 3-5; Qiang et al., 2011, pp. 14-26); (v) elimination of agricultural wastes through the mitigation of supply- and demand-side constraints as well as demand-supply mismatches (Muto \& Yamano, 2009; Aker \& Fafchamps, 2010); (vi) efficiency in the management of households (Al Surikhi, 2012; Asongu, 2014a, 2015c) and (v) enhancing of business opportunities (Ondiege, 2010, p. 11; Mishra \& Bisht, 2013, p. 505). The above justifications are linked to the inquiry in the perspective that, with good governance, the growth potential of mobile phones can be harnessed to address the policy syndrome of exclusive human development in SSA.

In addition to the above justifications for the present line of inquiry, there has also been growing requests in scholarly circles for more research on the development outcomes of mobile phones, partly because the phenomenon has been cautioned not to be considered as a silver bullet for development (Mpogole et al., 2008, p. 71; Asongu \& De Moor, 2015). In order to investigate the synergy effects of governance in mobile phones for inclusive development, we articulate the three main governance categories represented by six indicators, namely: (i) political governance (political stability/no violence and voice \& accountability); (ii) economic governance (government effectiveness and regulation quality) and (iii) institutional governance (corruption-control and the rule of law). Political governance is defined as the election and replacement of political leaders. Economic governance is the formulation and implementation of rules that enable the delivery of public commodities. Institutional governance is the respect of the State and citizens of institutions that govern interactions between them. Whereas the evolving literature substantiating the need to unbundle governance indicators is discussed in Section 2, the relevance of such unbundling is to avail room for more policy implications.

In light of the above, the main contribution of this inquiry is to extend the existing literature by assessing the role of governance in the inclusive human development benefits of mobile phone penetration. The remainder of the paper is presented as follows. The literature on governance, mobile phones and inclusive development is covered in Section 2. The data and methodology are discussed in Section 3. Section 4 presents the empirical results. Section 5 concludes with implications. 


\section{Governance, mobile phones and inclusive development}

\subsection{Controversial views and debates on the conception of governance}

We engage this section in three main themes, namely: (i) definitions of the concept of governance; (ii) controversial views on governance measurements in mainstream literature and (iii) the imperative of unbundling the concept of governnce in development literature.

In accordance with Asongu (2015d), various definitions to the concept of governance have been dcoumented. For brevity and lack of space, we limit the discourse to four main definitions from recent literature. First, economic govenance has been defined by Dixit (2009) as the '...structure and functioning of the legal and social institutions that support economic activity and economic transactions by protecting property rights, enforcing contracts, and taking collective action to provide physical and organizational infrastructure' (p.5). Second, Tusalem (2015) conceives governance as an embodiment of corruption, rule of law, political stability, bureaucratic effectiveness and regulatory quality. Third, according to Fukuyama (2013), the concept of governance can be improved by adopting four principal approaches through which 'state quality' can be understood, namely: (i) procedural measures, (ii) output measures; (iii) bureaucratic autonomy measures and (iii) indicators of capacity which are an embodiment of both resources and the degree of professionalism. Fourth, to the best of our knowledge, the most widely employed governance indicators from Kaufmann et al. (2010) can be classified into three main categories (see Andrés et al., 2014). (a) Political governance measures the election and replacement of political leaders and is approximated by: voice and accountability and political stability/non-violence. (b) Economic governance is defined as the formulation and implementation of policies that deliver public commodities and is proxied with regulation quality and government effectiveness. (c) Institutional governance is defined as the respect of the State and citizens of institutions that govern interactions between them and measured by the rule of law and corruption-control.

In the second theme, we devote space to briefly engaging several criticisms in academic circles that have arisen from the use of governance indicators from Kaufmann et al. (2010). As far as we have reviewed, the most notable of these criticisms is that debate between the underlying authors on the one hand and 'Andrew Schrank and Marcus Kurtz' on the other hand. The debate is discussed in four streams, namely: 'models, measures and mechanisms'; 'a reply'; 'a defense' and 'a rejoinder'.

Kurtz and Schrank (2007a) have raised doubts about the consensus that good governance is positively associated with economic development by presenting a case for 
rethinking the mainstream confidence enjoyed by the governance indicators from Kaufmann et al. in empirical literature on the governance-growth nexus. The authors have concluded that the underlying governance measurements are problematic because they are clouded with a number of issues, inter alia: sampling adverse selection, perceptual biases and conceptual conflation with choices of policy.

Kaufmann et al. (2007a) have replied to Kurtz and Schrank (2007a) with a three point argument to demonstrate that the claims by Schrank and Kurtz (2007a) are unsubstantiated. (i) They have first shown that claims from Kurtz and Schrank (2007a) on 'perception-base measurement biases' in the widely used governance indicators are falsifiable, speculcative and short of withstanding empirical scrutiny. (ii) They then provide empirical backing to support the argument that the short-term relationship advanced by Kurtz and Schrank (2007a) is statistically fragile and conceptually flawed. (iii) Lastly, the have dismissed the empirical study of the contenders on the effect of govenance on growth.

In defense of their position Kurtz and Schrank (2007b), have responded to Kaufmann et al. (2007a) by further articulating that the underpinning concerns about conceptual clarity and corresponding measurement are deeply seated in the debate surrounding the governancegrowth relationship. Kaufmann et al. (2007b) have also responded in a brief rejoinder by reiterating the lack of empirical justification for the criticisms sustained by Kurtz and Schrank (2007b). Kaufmann et al. (2007b) have further articulated that concerns about 'potential respondant bias' posited by Kurtz and Schrank (2007ab) also apply to other variables because, they are not exclusively limited to the measurement of government effectiveness. In light of the above, this line of inquiry shall adopt the governance concepts of Kaufmann et al. (2007ab, 2010). Consistent with recent literature on the need to unbundle govenance measurements for more development outcomes and greater subtlety in policy implication, we employ the six main governance indicators.

In the third theme, as emphasised by Asongu (2015d), the motivation for employing all governance indicators builds on a recent stream of literature on unbundling institutions in African development, notably: (i) regulation quality and government effectiveness being the most important indicators in stimulating innovation (Oluwatobi et al., 2015); (ii) corruptioncontrol being the most effective weapon in the fight against software piracy (Andrés \& Asongu, 2013) and conflicts/crimes (Asongu \& Kodila-Tedika, 2016); (iii) the role of formal institutions in the promotion of knowledge economy (Andrés et al., 2014) and (iv) the 
deterioration of governance in the prediction and timing of the Arab Spring (Asongu \& Nwachukwu, 2015).

\subsection{Mobile phones penetration and inclusive development}

In addition to easing the doing of business (Kumar \& Zahn, 2003; Kuoa \& Yub, 2006; Jin \& von Zedtwitz, 2008; Lee et al., 2010), the mobile revolution has generated a plethora of inclusive development benefits to developing countries. According to recent African development literature (Asongu \& De Moor, 2015), the revolution of the mobile phone has touched almost every societal fabric in Africa. The narrative sustains that it has improved both household and corporate management by constantly consolidating networks of interaction which include, inter alia: (i) improved payment facilities for Small and Medium Size Enterprises (SMEs); (ii) enhanced business-to-business interactions; (iii) better mechanisms for health-care monitoring; (iv) upgraded household-to-household as well as household-tobusiness interactions; (v) reduction of development gaps between rural and urban areas and (vi) improved household and corporate management through continuous upgrade of networks of interaction.

We briefly discuss the inclusive benefits of mobile phone penetration in three main themes, notably, in: enhancement of health services, reduction of the gender gap and mitigation of the rural/urban divide. In the first theme on health services, there is growing evidence that mobile phones are being used for the delivery of health services. In essence, the device has been instrumented to provide more affordable medical services (West, 2013). Therefore, income and geography constraints, formerly inhibiting 'health care delivery' are being increasingly mitigated with mobile services. Some mechanisms through which medical services have been improved include: laboratory tests, medical recording and access to material of reference. Accordingly, medical devices are growingly being adapted for, inter alia: better treatment and observation of tuberculosis patients (Hoffman et al., 2010); improved tailored feedback due to enhanced self-monitoring (Bauer et al., 2010) and efficient management of clinical appointments (De Costa et al., 2010). According to Kliner et al. (2013), communities in rural areas are benefiting most from health-oriented mobile applications. This position is confirmed by a study of the same year supporting the negative poverty externalities of mobile phone applications in rural areas: 'We conclude that mobile phone-based money transfer services in rural areas help to resolve a market failure that farmers face; access to financial services' (Kirui et al., 2013, p. 141). The first strand 
fundamentally builds on the notion that targeted spending on health services is critical to bridging the rural-urban gap (Ssozi \& Amlani, 2015).

The second theme documents evidence of mechanisms by which the rural-urban divide can be reduced, notably via: (i) tackling issues of unemployment, food production and distribution in rural areas; (ii) supporting SMEs and cooperatives and (iii) reducing supplyand demand-side constraints in agricultural productivity. Mobile phones are increasingly being employed to tackle challenges to employment, production and distribution of supplies in food. For instance, in Ghana, a study has established that reduction of information asymmetry with the help of the mobile phone augments the income of traders by about $10 \%$ (E-agriculture, 2012, p. 6-9). Mobile phones are being complemented with agricultural finance to support SMEs and cooperatives. A notable example from Perez et al. (2011, p. 316) is the Community Credit Enterprises (CCE) in Costa Rica through: (i) support to financiallysustainable groups and (ii) enhancement of the sustainability of business models. In accordance with the engaged literature, the mobile phone is growingly being employed to improve living standards in rural areas by reducing demand- and supply-side constraints in agricultural productivity (Muto \& Yamano, 2009; Aker \& Fafchamps, 2010). Consistent with Asongu and De Moor (2015), this mitigation of constraints with better networking and 'matching practices' mechanisms have improved agricultural returns for farmer in rural areas.

The three streams above are in line with the stance of the World Bank that mobile phones are imperative for agricultural and rural development (Qiang et al., 2011, pp. 14-26). Chan and Jia (2011) have supported this view on the benefits of mobile phones in easing financial access 'mobile banking is an ideal choice for meeting the rural financial needs' ( $\mathrm{p}$. 3) partly because of increasing 'rates for bank transfers through mobile cell phones at commercial banks' (p. 5). The positive gains from mobile telephony are more skewed towards underprivileged citizens in rural areas (Warren, 2007), probably because it helps to uplift more barriers to the purchase of goods and information acquisition. For instance, in India, the mobile phone is increasing financial inclusion (Singh, 2012, p. 466) in rural areas because 'Telecommunication infrastructure growth especially mobile phone penetration has created an opportunity for providing financial inclusion' (Mishra \& Bisht, 2013, p. 503).

In the third theme, we briefly discuss some recent evidence on the reduction of the gender-divide. Accordingly, there is growing evidence that mobile phones empower women via enhanced channels of financial inclusion. These mechanisms entail improved coordination of female-managed SMEs as well as household activities (Asongu, 2014a). Other documented 
activities on gender inclusion have included: cost reduction, education and multi-tasking (Al Surikhi, 2012; Jonathan \& Camilo, 2008; Ondiege, 2010, 2013; Asongu, 2014a, 2015b). According to Asongu and De Moor (2015), government intervention is imperative for females to enjoy the financial inclusive rewards of mobile phones. Other studies consistent with this narrative have included: (i) Ojo et al. (2012) articulating the usage of mobile phones to enhance the livelihood of women in Ghana and (ii) Maurer (2008) sustaining the relevant role of policy in consolidating the gender inclusive benefits of mobile phones. We invite the interested reader to consult Ondiege (2010, p. 11) and Bisht (2013, p. 505) for countryspecific strategies/approaches.

In light of the above, to the best our knowledge the available literature has not focused on the complementary role of governance in mobile phone penetration for inclusive development.

\section{Data and methodology}

\subsection{Data}

We assess a panel of 49 SSA countries with data from African Development Indicators of the World Bank for the period 2000-2012. Consistent with recent African inclusive development literature (Asongu et al., 2015), the dependent is the inequality adjusted human development index (IHDI) while the mobile telephony variable is measured by the mobile phone penetration rate (per 100 people), in line with recent African knowledge economy literature (Tchamyou, 2015). In accordance with the justifications provided in Section 2, the six governance indicators from Kaufmann et al. (2010) are: (i) voice \& accountability and political stability/no violence for political governance; (ii) government effectiveness and regulation quality for economic governance; and (iii) corruption-control and the rule of law for institutional governance. These indicators have also been used in recent governance literature (see Gani, 2011; Andrés et al., 2014; Yerrabit \& Hawkes, 2015; Asongu \& Nwachukwu, 2016).

Selected control variable are: GDP per capita growth, private domestic credit, foreign direct investment (FDI) and remittances. We expect a positive relationship between these covariates and inclusive human development; in line with recent inclusive growth literature (see Anand et al., 2012; Mishra et al., 2011; Seneviratne \& Sun, 2013; Mlachila et al., 2014). In essence: (i) per capita economic growth, FDI and credit facilities are needed for 'social spending' that improves human development (Mlachila et al., 2014) while (ii) remittances 
which are used for consumption purposes for the most part are also very likely to enhance human development (Mlachila et al., 2014; Ssozi \& Asongu, 2015).

The definition and sources of variables are provided in Appendix 1, the summary statistics in Appendix 2 whereas Appendix 3 discloses the correlation matrix. From the summary statistics: (i) the means of the variables are comparable and (ii) in light of corresponding variations, we can be confident that reasonable estimated linkages would emerge. The purpose of the correlation matrix is to avoid concerns of multicollinearity. We notice that concerns about degrees of substitution among variables are apparent among governance variables. However, consistent with the narrative in Section 2 on the need to unbundle governance indicators, conceptual priority takes precedence over degrees of substitution. To this end, we: (i) do not bundle the variables by means of principal component analysis and (ii) employ the six governance variables independently in distinct specifications to avoid concerns of multicollinearity.

\subsection{Methodology}

We adopt three main empirical strategies, which control for: (i) the unobserved heterogeneity with Fixed effects (FE) regression; (ii) persistence in the dependent variable with the Generalised Method of Moments (GMM) that increases the bite on endogeneity and (iii) the limited range of the dependent variable with the Tobit model.

The panel FE model is presented as follows:

$$
I H D_{i, t}=\partial_{0}+\partial_{1} M_{i, t}+\partial_{2} G_{i, t}+\partial_{3} M G_{i, t}+\sum_{h=1}^{4} \omega_{h} W_{h, i, t-\tau}+\eta_{i}+\varepsilon_{i, t}
$$

Where: $I H D_{i, t}$ is inclusive human development of country $i$ at period $t ; \partial$ is a constant; $M$, mobile phone penetration; $G$, Governance (Voice \& accountability, political stability/ no violence, government effectiveness, regulation quality, corruption-control and rule of law) ; $M G$, interaction between mobile phone penetration (M) and Governance (G); $W$ is the vector of control variables (GDP per capita growth, Private domestic credit, Remittances and Foreign direct investment); $\eta_{i}$ is the country-specific effect and $\varepsilon_{i, t}$ the error term.

Since, the estimation strategy involves interactive regressions; it is important to engage some pitfalls associated with these types of regressions documented by Brambor et al. (2006). Accordingly, all constitutive variables should enter into the specifications. Moreover, 
for the estimations to have economic meaning, corresponding estimated parameters from interactive terms should be interpreted as conditional marginal impacts.

Consistent with Asongu (2013b), there is at least a threefold reason for adopting the GMM approach. Accordingly, it: (i) controls for potential endogeneity in all regressors; (ii) reduces potential biases of the difference estimator in small samples and (iii) does not eliminate cross-country differences. Whereas the system GMM estimation (Arellano \& Bover, 1995; Blundell \& Bond, 1998) has been preferred to the difference estimator (Arellano \& Bond, 1991) as justified by Bond et al. (2001, pp. 3-4), we adopt the recent approach that employs forward orthogonal deviations. This is an extension of Arellano and Bover (1995) by Roodman (2009ab) and has been documented to account for cross-sectional independence and limit over-identification or instrument proliferation (Love \& Zicchino, 2006; Baltagi, 2008). In the specification, we employ a two-step GMM with forward orthogonal deviations instead of differencing. The two-step approach is preferred to the one-step because it is consistent with heteroscedasticity,

The following equations in levels (2) and first difference (3) summarize the standard system GMM estimation procedure.

$$
\begin{aligned}
& I H D_{i, t}=\sigma_{0}+\sigma_{1} I H D_{i, t-\tau}+\sigma_{2} M_{i, t}+\sigma_{3} G_{i, t}+\sigma_{4} M G_{i, t}+\sum_{h=1}^{4} \delta_{h} W_{h, i, t-\tau}+\eta_{i}+\xi_{t}+\varepsilon_{i, t} \\
& I H D_{i, t}-I H D_{i, t-\tau}= \sigma_{0}+\sigma_{1}\left(I H D_{i, t-\tau}-I H D_{i, t-2 \tau}\right)+\sigma_{2}\left(M_{i, t}-M_{i, t-\tau}\right)+\sigma_{3}\left(G_{i, t}-G_{i, t-\tau}\right)+\sigma_{3}\left(M G_{i, t}-M G_{i, t-\tau}\right) \\
&+\sum_{h=1}^{4} \delta_{h}\left(W_{h, i, t-\tau}-W_{h, i, t-2 \tau}\right)+\left(\xi_{t}-\xi_{t-\tau}\right)+\varepsilon_{i, t-\tau}
\end{aligned}
$$

Where: $\tau$ represents tau and $\xi_{t}$ is the time-specific constant.

Given that the IHDI theoretically falls between 0 and 1, Ordinary Least Squares (OLS) may be inappropriate. To this end, many authors have employed double-censored Tobit models to control for the limited range of the dependent variable (Kumbhakar \& Lovell, 2000; Koetter et al., 2008; Ariss, 2010; Coccorese \& Pellecchia, 2010). In accordance with recent literature (McDonald, 2009; Coccorese \& Pellecchia, 2010), if there are no observations of either 0 or 1 for the IHDI (which is the case here), estimating by a double-censored Tobit model is the same as estimating by a linear regression model since the two likelihood functions coincide. Therefore, the logistic regression associated with the Tobit model is as follows: 
$I H D_{i t}=\frac{\exp \left(x_{i t}^{\prime} \beta\right)}{1+\exp \left(x_{i t}^{\prime} \beta\right)}+\phi_{i t}$

where $x_{i t}$ is the same vector of regressors used in the Tobit model, $\beta$ is the vector of parameters and $\phi_{i t}$ is independently and identically distributed (iid) with mean zero and variance $\sigma_{\phi}^{2}$ variance.

\section{Empirical results}

\subsection{Presentation of results}

Table 1 below presents the FE findings for which we have controlled for the unobserved heterogeneity in terms of country-specific effects. The following findings can be established. Mobile phones consistently increase inclusive human development in SSA. Economic governance increases inclusive human development, albeit with the government effectiveness tool exerting a higher magnitude relative to regulation quality. Only the rule of law dimension of institutional governance significantly increases inclusive development. The effect of political governance is not significant. Significant synergy effects are not apparent. The significant control variables have expected signs. Accordingly, we expected GDP per capita growth, remittances and FDI to positively affect inclusive human development.

We have observed from FE regressions that synergy effects appreciating the interaction between governance and mobile phones variables are not consistently significant. It is important to note that the system GMM equation is tailored such that, its first difference equation eliminates country FE (see Eq. (3)). However, the GMM approach controls for timeinvariant omitted variables which represent some bite on endogeneity. Moreover, at least two conditions are necessary for the application of the GMM, notably: (i) the dependent variable should be persistent and (ii) the number of cross-sections should exceed the number of years in each time series $(\mathrm{N}>\mathrm{T})$. The latter is respected since we have 49 countries $(\mathrm{N})$ and 13 years (T). The former also holds because the correlation between the IHDI and its first lag is 0.999, which is higher than the rule of thumb threshold of 0.800 needed to ascertain the persistence of the dependent variable (Asongu \& De Moor, 2016). 
Table 1: Inclusive development and mobile phones (Fixed Effects)

Constant

Mobile phones (Mob)

Political Stability

Voice \& Accountability

Government Effectiveness

Regulation Quality

Corruption Control

Rule of Law

'Political Stability’ $\times$ Mob

'Voice \& Accountability’ ×Mob

'Government Effectiveness'×Mob

'Regulation Quality'×Mob

'Corruption Control' $\times$ Mob

'Rule of Law' $\times$ Mob

GDP per capita growth

Private Domestic Credit

Remittances

Foreign Direct Investment

Adjusted R²(within)

Fisher

Countries

Observations

Dependent Variable: Inequality Adjusted Human Development (IHDI)

\begin{tabular}{cc|}
\multicolumn{2}{c|}{ Political Governance } \\
Political & Voice \& \\
Stability (PolS) & Accountability(VA)
\end{tabular}

\begin{tabular}{|c|c|c|c|}
\hline \multicolumn{2}{|c|}{ Political Governance } & \multicolumn{2}{|c|}{ Economic Governan } \\
\hline Political & Voice \& & Government & Regulati \\
\hline Stability (PolS) & Accountability(VA) & $\begin{array}{l}\text { Effectiveness } \\
(\mathrm{GE})\end{array}$ & Quality( \\
\hline $0.428 * * *$ & $0.429 * * *$ & $0.444 * * *$ & $0.438 * *$ \\
\hline$(0.000)$ & $(0.000)$ & $(0.000)$ & $(0.000)$ \\
\hline $0.0006 * * *$ & $0.0007 * * *$ & $0.0006 * * *$ & $0.0006 *$ \\
\hline$(0.000)$ & $(0.000)$ & $(0.000)$ & $(0.000)$ \\
\hline-0.001 & --- & --- & --- \\
\hline \multicolumn{4}{|l|}{$(0.805)$} \\
\hline \multirow[t]{2}{*}{--- } & 0.001 & --- & --- \\
\hline & $(0.887)$ & & \\
\hline \multirow[t]{2}{*}{---} & --- & $0.024 * *$ & --- \\
\hline & & $(0.012)$ & \\
\hline \multirow[t]{2}{*}{--- } & --- & --- & $0.015 *$ \\
\hline & & & $(0.094)$ \\
\hline
\end{tabular}

$--$

$-$

$-0.00004$

(0.410)

$---$

$$
--
$$

0.00009

$(0.225)$

---

$---$

$--$

$---$

$\begin{array}{ll}\mathbf{0 . 0 0 1} * * * & \mathbf{0 . 0 0 1} * * * \\ (\mathbf{0 . 0 0 1 )} & (\mathbf{0 . 0 0 2 )} \\ -0.00001 & -0.00002 \\ (0.958) & (0.933) \\ \mathbf{0 . 0 0 0 7} * & \mathbf{0 . 0 0 0 7} * * \\ (\mathbf{0 . 0 6 4 )} & (\mathbf{0 . 0 4 0 )} \\ \mathbf{0 . 0 0 0 4} * * & \mathbf{0 . 0 0 0 4} * * \\ (\mathbf{0 . 0 2 9}) & (\mathbf{0 . 0 2 0}) \\ 0.439 & 0.441 \\ \mathbf{2 9 . 6 2} * * * & \mathbf{2 9 . 7 7} * * * \\ 39 & 39 \\ 310 & 310\end{array}$

$-0.00009$

(0.237)

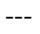

$--$

$0.001 *$

(0.002)

0.000008

(0.981)

.0006*

(0.071)

0.0004*

(0.054)

0.452

31.13***

39

310

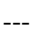

---

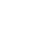

$--$

$--$

$--$

$-0.00001$

(0.870)
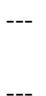

$0.001 * * *$

(0.001)

$-0.00008$

(0.822)

0.0006*

(0.071)

0.0004*

(0.065)

0.444

30.11***

39

310
Institutional Governance

Corruption- Rule of Law

Control (CC) (RL)

$0.429 * * * \quad 0.449 * * *$

(0.000) (0.000)

$0_{0.0006}^{* * *} \quad 0.0006 * * *$

(0.000) (0.000)

$---$

0.002

(0.770)

$\mathbf{0 . 0 3 0} * * *$

(0.001)

$---$

$---$

$-0.00008$

(0.240)

$---$

0.00009

(0.899)

$0.001 * * *$

(0.002)

$\begin{array}{ll}-0.000009 & -0.0001 \\ (0.978) & (0.769)\end{array}$

(0.978)

0.0005

(0.123)

(0.057)

0.0003*

$0.0004 * *$

(0.073)

0.440

0.462

29.74***

32.50***

39

310

$*, * *, * * *$ : significance levels of $10 \%, 5 \%$ and $1 \%$ respectively. GDP: Gross Domestic Product 


\begin{tabular}{|c|c|c|c|c|c|c|}
\hline & \multicolumn{6}{|c|}{ Dependent Variable: Inequality Adjusted Human Development (IHDI) } \\
\hline & \multicolumn{2}{|c|}{ Political Governance } & \multicolumn{2}{|c|}{ Economic Governance } & \multicolumn{2}{|c|}{ Institutional Governance } \\
\hline & $\begin{array}{c}\text { Political } \\
\text { Stability (PolS) }\end{array}$ & $\begin{array}{c}\text { Voice \& } \\
\text { Accountability(VA) }\end{array}$ & $\begin{array}{c}\text { Government } \\
\text { Effectiveness } \\
\text { (GE) }\end{array}$ & $\begin{array}{c}\text { Regulation } \\
\text { Quality(RQ) }\end{array}$ & $\begin{array}{l}\text { Corruption- } \\
\text { Control (CC) }\end{array}$ & $\begin{array}{c}\text { Rule of Law } \\
\text { (RL) }\end{array}$ \\
\hline Constant & $\begin{array}{l}\mathbf{0 . 0 4 3} * * * \\
(\mathbf{0 . 0 0 0 )}\end{array}$ & $\begin{array}{l}0.052 * * * \\
(\mathbf{0 . 0 0 0 )}\end{array}$ & $\begin{array}{l}\mathbf{0 . 0 5 3} * * * \\
(\mathbf{0 . 0 0 0 )}\end{array}$ & $\begin{array}{l}0.084 * * * \\
(0.000)\end{array}$ & $\begin{array}{l}0.055 * * * \\
(\mathbf{0 . 0 0 0 )}\end{array}$ & $\begin{array}{l}\text { 0.0731**** } \\
(\mathbf{0 . 0 0 0 )}\end{array}$ \\
\hline IHDI $(-1)$ & $\begin{array}{l}0.843 * * * \\
(0.000)\end{array}$ & $\begin{array}{l}0.826 * * * * \\
(0.000)\end{array}$ & $\begin{array}{l}0.829 * * * \\
(0.000)\end{array}$ & $\begin{array}{l}0.814 * * * \\
(0.000)\end{array}$ & $\begin{array}{l}0.794 * * * \\
(0.000)\end{array}$ & $\begin{array}{l}0.758^{* * * *} \\
(0.000)\end{array}$ \\
\hline Mobile phones (Mob) & $\begin{array}{l}\text { 0.0004**** } \\
(0.000)\end{array}$ & $\begin{array}{l}0.0005 * * * \\
(0.000)\end{array}$ & $\begin{array}{l}0.0005 * * * \\
(0.000)\end{array}$ & $\begin{array}{l}0.0004 * * * \\
(0.000)\end{array}$ & $\begin{array}{l}0.0005 * * * \\
(0.000)\end{array}$ & $\begin{array}{l}0.0005 * * * \\
(0.000)\end{array}$ \\
\hline Political Stability & $\begin{array}{l}-0.001 \\
(0.638)\end{array}$ & --- & --- & --- & --- & --- \\
\hline Voice \& Accountability & --- & $\begin{array}{l}0.003 * \\
(0.054)\end{array}$ & --- & --- & --- & --- \\
\hline Government Effectiveness & --- & --- & $\begin{array}{l}0.009 * * * \\
(0.008)\end{array}$ & --- & --- & --- \\
\hline Regulation Quality & --- & --- & --- & $\begin{array}{l}0.015 * * * \\
(0.000)\end{array}$ & --- & --- \\
\hline Corruption Control & --- & --- & --- & --- & $\begin{array}{l}0.007 * * * \\
(0.004)\end{array}$ & --- \\
\hline Rule of Law & --- & --- & --- & --- & --- & $\begin{array}{l}0.009 * * * * \\
(0.000)\end{array}$ \\
\hline 'Political Stability' $\times$ Mob & $\begin{array}{l}-0.000005 \\
(0.895)\end{array}$ & --- & --- & --- & --- & --- \\
\hline 'Voice \& Accountability' $\times$ Mob & --- & $\begin{array}{l}0.00002 \\
(0.468)\end{array}$ & --- & --- & --- & --- \\
\hline 'Government Effectiveness’ $\times$ Mob & --- & --- & $\begin{array}{l}0.000009 \\
(0.842)\end{array}$ & --- & --- & --- \\
\hline ‘Regulation Quality’×Mob & --- & --- & --- & $\begin{array}{l}0.00004 * \\
(0.050\end{array}$ & --- & --- \\
\hline 'Corruption Control' $\times$ Mob & --- & --- & --- & --- & $\begin{array}{l}-0.00006 \\
(0.161)\end{array}$ & --- \\
\hline 'Rule of Law'×Mob & --- & --- & --- & --- & --- & $\begin{array}{l}-0.00002 \\
(0.472)\end{array}$ \\
\hline GDP per capita growth & $\begin{array}{l}0.0005^{* * * *} \\
(0.000)\end{array}$ & $\begin{array}{l}0.0004 * * * \\
(0.000)\end{array}$ & $\begin{array}{l}0.0005 * * * \\
(0.000)\end{array}$ & $\begin{array}{l}0.0005 * * * \\
(0.000)\end{array}$ & $\begin{array}{l}0.0004 * * * \\
(0.000)\end{array}$ & $\begin{array}{l}0.0003 * * * \\
(0.000)\end{array}$ \\
\hline Private Domestic Credit & $\begin{array}{l}0.0002 \\
(0.315)\end{array}$ & $\begin{array}{l}0.0002 \\
(0.160)\end{array}$ & $\begin{array}{l}0.000001 \\
(0.990)\end{array}$ & $\begin{array}{l}-0.0001 \\
(0.374)\end{array}$ & $\begin{array}{l}0.0005 * * * \\
(0.005)\end{array}$ & $\begin{array}{l}0.0005 * * * \\
(0.000)\end{array}$ \\
\hline Remittances & $\begin{array}{l}0.0001 \\
(0.277)\end{array}$ & $\begin{array}{l}\text { 0.0003* } \\
(0.088)\end{array}$ & $\begin{array}{l}0.000009 \\
(0.955)\end{array}$ & $\begin{array}{l}0.0004 * * * \\
(0.002)\end{array}$ & $\begin{array}{l}0.0002 * \\
(0.088)\end{array}$ & $\begin{array}{l}0.0004 * * * \\
(0.003)\end{array}$ \\
\hline Foreign Direct Investment & $\begin{array}{l}0.0002^{* * * *} \\
(0.003)\end{array}$ & $\begin{array}{l}0.0002 * * * \\
(0.003)\end{array}$ & $\begin{array}{l}0.0003 * * * \\
(0.000)\end{array}$ & $\begin{array}{l}0.0002 * * * \\
(0.000)\end{array}$ & $\begin{array}{l}0.0002 * * * \\
(0.001)\end{array}$ & $\begin{array}{l}0.0002 * * * * \\
(0.001)\end{array}$ \\
\hline $\mathrm{AR}(1)$ & $(0.090)$ & $(0.087)$ & $(0.075)$ & $(0.026)$ & $(0.289)$ & $(\mathbf{0 . 3 5 2})$ \\
\hline $\operatorname{AR}(2)$ & $(0.621)$ & $(0.743)$ & $(0.915)$ & $(0.641)$ & $(0.973)$ & $(0.461)$ \\
\hline Sargan OIR & $(0.000)$ & $(0.000)$ & $(0.000)$ & $(0.000)$ & $(0.000)$ & $(0.000)$ \\
\hline Hansen OIR & $(0.692)$ & $(0.626)$ & $(\mathbf{0 . 3 8 7})$ & $(\mathbf{0 . 2 3 1})$ & $(0.521)$ & $(\mathbf{0 . 5 5 0})$ \\
\hline $\begin{array}{l}\text { DHT for instruments } \\
\text { (a)Instruments in levels }\end{array}$ & $(0.637)$ & $(0.575)$ & $(0.603)$ & $(0.645)$ & $(0.601)$ & $(0.876)$ \\
\hline H excluding group & $(0.599)$ & $(0.556)$ & $(0.274)$ & $(0.126)$ & $(0.415)$ & $(0.293)$ \\
\hline $\begin{array}{l}\text { Dif(null, H=exogenous) } \\
\text { (b) IV (years, eq(diff)) }\end{array}$ & & & & & & \\
\hline $\mathrm{H}$ excluding group & $(0.471)$ & $(0.297)$ & $(\mathbf{0 . 1 9 8})$ & $(0.474)$ & $(0.347)$ & $(0.122)$ \\
\hline Dif(null, $\mathrm{H}=$ exogenous) & $(\mathbf{0 . 7 8 7})$ & $(0.902)$ & $(0.717)$ & $(0.129)$ & $(0.678)$ & $(0.997)$ \\
\hline Fisher & $358750.35 * * *$ & $93951.21 * * *$ & $1590000 * * *$ & $134730.84 * * *$ & $101114.55 * * * *$ & $37327.28 * * *$ \\
\hline Instruments & 40 & 40 & 40 & 40 & 40 & 40 \\
\hline Countries & 38 & 38 & 38 & 38 & 38 & 38 \\
\hline Observations & 261 & 261 & 261 & 261 & 261 & 261 \\
\hline
\end{tabular}


*, **, ***: significance levels of $10 \%, 5 \%$ and $1 \%$ respectively. GDP: Gross Domestic Product.. DHT: Difference in Hansen Test for Exogeneity of Instruments' Subsets. Dif: Difference. OIR: Over-identifying Restrictions Test. The significance of bold values is twofold. 1) The significance of estimated coefficients, Hausman test and the Fisher statistics. 2) The failure to reject the null hypotheses of: a) no autocorrelation in the $A R(1)$ and $A R(2)$ tests and; b) the validity of the instruments in the Sargan $O I R$ test.

In accordance with Asongu and De Moor (2016), we employ four main information criteria to assess the validity of corresponding models. First, the null hypothesis of the second-order Arellano and Bond autocorrelation test $(\operatorname{AR}(2))$ in difference for the absence of autocorrelation in the residuals should not be rejected. Second, the Sargan and Hansen overidentification restrictions (OIR) tests should also not be significant because their null hypotheses are the positions that instruments are not correlated with the error terms, implying they are valid. Accordingly, whereas the Sargan OIR test is not weakened by instruments and not robust, the Hansen OIR is weakened by instruments but robust. Third, we complement the Sargan OIR and Hansen OIR tests with the Difference in Hansen Test (DHT) for exogeneity of instruments. Fourth, a Fischer test for the joint validity of estimated coefficients is also provided.

The following findings are established. There is some evidence of catch-up in inclusive human development because the absolute values of the lagged endogenous variables are consistently between 0 and 1 . We invite the interested reader to refer to Fung (2009, p. 58) and Asongu (2013b, p. 49) for more insights into the convergence criterion. Mobile phone penetration consistently increases human development. With the exception of political stability, all governance variables have positive impacts on inclusive development. Only the marginal effect from regulation quality is significantly positive. All the significant control variables have the expected positive signs.

As discussed in Section 3.2, the Tobit model is appropriate when the dependent variable is limited. Since the IHDI varies between 0 and 1 , we control for the limited range of the dependent variable by employing a double censored Tobit model to establish the following findings. Mobile phones consistently increase inclusive human development. With the exception of political governance from which effects are insignificant, the impacts from constituents of economic governance and institutional governance are positive. Positive synergy effects are observed from political governance (political stability and voice \& accountability) and the rule of law. The significant control variable has the expected sign. 
Constant

Mobile phones (Mob)

Political Stability

Voice \& Accountability

Government Effectiveness

Regulation Quality

Corruption Control

Rule of Law

'Political Stability’ $\times$ Mob

'Voice \& Accountability' $\times$ Mob

'Government Effectiveness’ $\times$ Mob

'Regulation Quality’×Mob

'Corruption Control' $\times \mathrm{Mob}$

'Rule of Law' $\times$ Mob

GDP per capita growth

Private Domestic Credit

Remittances

Foreign Direct Investment

LR Chi-Square

Log Likelihood

Observations

Dependent Variable: Inequality Adjusted Human Development (IHDI)

\begin{tabular}{|c|c|c|c|c|c|}
\hline \multicolumn{2}{|c|}{ Political Governance } & \multicolumn{2}{|c|}{ Economic Governance } & \multicolumn{2}{|c|}{ Institutional Governance } \\
\hline $\begin{array}{l}\text { Political } \\
\text { Stability (PolS) }\end{array}$ & $\begin{array}{l}\text { Voice \& } \\
\text { Accountability(VA) }\end{array}$ & $\begin{array}{l}\text { Government } \\
\text { Effectiveness } \\
\text { (GE) }\end{array}$ & $\begin{array}{l}\text { Regulation } \\
\text { Quality(RQ) }\end{array}$ & $\begin{array}{l}\text { Corruption- } \\
\text { Control (CC) }\end{array}$ & $\begin{array}{l}\text { Rule of Law } \\
\text { (RL) }\end{array}$ \\
\hline $0.391 * * *$ & $0.385 * * *$ & $0.437 * * *$ & $0.417 * * *$ & $0.414 * * *$ & $0.412 * * *$ \\
\hline$(0.000)$ & $(0.000)$ & $(0.000)$ & $(0.000)$ & $(0.000)$ & $(0.000)$ \\
\hline $0.001 * * *$ & $0.001 * * *$ & $0.001 * * *$ & $0.001 * * *$ & $0.001 * * *$ & $0.001 * * *$ \\
\hline$(0.000)$ & $(0.000)$ & $(0.000)$ & $(0.000)$ & $(0.000)$ & $(0.000)$ \\
\hline $\begin{array}{l}0.009 \\
(0.168)\end{array}$ & --- & --- & --- & --- & --- \\
\hline --- & $\begin{array}{l}0.001 \\
(0.850)\end{array}$ & --- & --- & --- & --- \\
\hline--- & --- & $\begin{array}{l}0.059 * * * \\
(0.000)\end{array}$ & --- & --- & --- \\
\hline --- & --- & --- & $\begin{array}{l}0.057 * * * \\
(0.000)\end{array}$ & --- & --- \\
\hline--- & --- & --- & --- & $\begin{array}{l}0.042 * * * \\
(0.001)\end{array}$ & --- \\
\hline --- & --- & --- & --- & --- & $\begin{array}{l}0.030 * * * \\
(0.009)\end{array}$ \\
\hline $\begin{array}{l}0.0005 * * * \\
(0.001)\end{array}$ & --- & --- & --- & --- & --- \\
\hline--- & $\begin{array}{l}0.0005 * \\
(0.051)\end{array}$ & --- & --- & --- & --- \\
\hline--- & --- & $\begin{array}{l}0.0002 \\
(0.257)\end{array}$ & --- & --- & --- \\
\hline --- & --- & --- & $\begin{array}{l}-0.00009 \\
(0.748)\end{array}$ & --- & --- \\
\hline --- & --- & --- & --- & $\begin{array}{l}0.0003 \\
(0.196)\end{array}$ & --- \\
\hline --- & --- & --- & --- & --- & $\begin{array}{l}0.0005 * * \\
(0.022)\end{array}$ \\
\hline 0.001 & 0.0009 & 0.0002 & 0.001 & 0.001 & 0.0008 \\
\hline$(0.360)$ & $(0.436)$ & $(0.816)$ & $(0.168)$ & $(0.389)$ & $(0.478)$ \\
\hline $0.001 * * *$ & $0.001 * * *$ & $0.0005 *$ & $0.0009 * * *$ & $0.0009 * * *$ & $0.0008 * * *$ \\
\hline$(0.000)$ & $(0.001)$ & $(0.054)$ & $(0.003)$ & $(0.000)$ & $(\mathbf{0 . 0 0 5 )}$ \\
\hline 0.0001 & 0.0002 & -0.0001 & 0.0002 & 0.0006 & -0.00006 \\
\hline$(0.700)$ & $(0.665)$ & $(0.823)$ & $(0.682)$ & $(0.183)$ & $(0.891)$ \\
\hline-0.0005 & -0.0007 & 0.00007 & -0.0001 & -0.0003 & -0.0003 \\
\hline$(0.325)$ & $(0.224)$ & $(0.902)$ & $(0.805)$ & $(0.518)$ & $(0.545)$ \\
\hline $227.89 * * *$ & $202.98 * * *$ & $246.03 * * *$ & $222.80 * * *$ & $230.61 * * *$ & $232.68 * * *$ \\
\hline 360.390 & 347.934 & 369.457 & 357.844 & 361.746 & 362.783 \\
\hline 310 & 310 & 310 & 310 & 310 & 310 \\
\hline
\end{tabular}

*, **, ***: significance levels of $10 \%, 5 \%$ and $1 \%$ respectively. GDP: Gross Domestic Product.

\subsection{Further discussion of results}

This section is engaged in three main theme, namely: the effect of mobile phones, the impact of governance (implications for policy), synergy effects (implications for practice) and convergence in inclusive development (implications for theory).

\subsubsection{Implications for policy}


First, we have confirmed the positive correlation between mobile phones and inclusive human development in Africa previously established by Asongu (2014a, 2015b). It is important to note that the underlying studies have been based on cross-sectional data. Hence, the requirement of a positive effect for sound policy implications has been established by the present inquiry. As a policy implication, the mobile revolution remains a source of inclusive development and pro-poor growth in SSA. Hence, given that more than $45 \%$ of countries in the sub-region are off-track from achieving the MDG extreme poverty target, the mobile phone can play a crucial role in the post-2015 development agenda if good policies are put in place by the governments of sampled countries in order to maximise the established inclusive benefits, in view of achieving Sustainable Development Goals (SDGs) that are fundamentally centred on sustained inclusive development. This leads us to the second strand on the role of governance in these projected benefits.

The literature engaged in Section 2 has articulated the need for better governance policies in view of maximising the potential inclusive development benefits of mobile phones (e.g. see Maurer, 2008). Two main trends draw our attention from the findings on the effect of governance: (i) whereas political governance is overwhelmingly not significant across estimated models, (ii) average effects from economic governance on inclusive development are higher relative to institutional governance. We devote space to provide more insights into these trends. First, the fact that economic governance has the highest effect on inclusive development can be justified from conceptual and empirical standpoints. (1) From a conceptual perspective, compared to institutional and political governances, economic governance is by definition the most closely related governance concept to human development because it entails, the formulation and implementation of policies that deliver public goods. These public goods embody facilities that are conceptually very close to the IHDI, inter alia: heath, educational and social amenities. (2) Oluwatobi et al. (2015) have assessed the role of governance components in stimulating innovative development in Africa and found economic governance to be the most effective governance mechanism. Second, the insignificant effect of political governance (compared to economic governance) may be traceable to the fact that priorities in political governance as opposed to economic governance engender less development rewards at the early stages of industrialisation. It is important to clarify the sequence of governance in the development process. In essence, according to recent literature, economic institutions should be prioritised over political institutions at the initial stages of economic development in order for governance to deliver public commodities. 
The interested reader can find country-specific and continental evidence in Kramon (2009) and Anyanwu and Erhijakpor (2014) respectively. As a policy implication, in increasing order, political governance, institutional governance and economic governance are positively associated with inclusive human development.

\subsubsection{Implications for practice}

In the third theme, we assess how the main problem statement of this line of inquiry has been addressed by discussing the synergy effects from interactions between the mobile phone and governance variables. Whereas no significant synergy effects are apparent in FE regressions, there are significant synergy impacts in the GMM and Tobit estimations, notably, from: (i) regulation quality in the former and (ii) political stability, voice \& accountability and the rule of law in the latter. However, consistent with Brambor et al. (2006) on pitfalls of interactive regressions, we cannot establish policy implications exclusively on synergy impacts. Hence, there is need to compute net effects. (1) The net effect from regulation quality in GMM regressions is $0.0003714([0.00004 \times-0.715]+0.0004)$. (2) Net effects corresponding to Tobit regressions are: (i) $0.0007285([0.0005 \times-0.543]+0.001)$ for political stability; (ii) $0.000677([0.0005 \times-0.646]+0.001)$ for voice $\&$ accountability and (iii) $0.000679([0.0005 \times-0.642]+0.001)$ for the rule of law. As a policy implication, governance can consolidate the gains of inclusive development from mobile phones. However, the corresponding low net effects imply that governance standards need to be improved in order to accelerate the underlying inclusive gains in the post-2015 development agenda.

\subsubsection{Implications for theory}

Fourth, it is important to highlight the policy relevance of convergence that is apparent from the GMM findings. Accordingly, we have consistently observed that the information criterion for convergence holds because the absolute value of the lagged endogenous variable is between 0 and 1. The finding is consistent with recent findings by Asongu (2014b) who has established evidence of convergence in the IHDI with data from 38 African countries for the period 1981 to 2009, albeit, the IHDI converging slower than some of its constituent components. The implication of the established evidence of convergence is that countries with lower levels of inclusive human development in SSA are catching-up their counterparts with higher levels of inclusive development. This line of interpretation extends the theoretical underpinnings of income convergence to other fields of economic and human developments. 
Overall the established role of mobile phones on inclusive development is consistent with the engaged literature. The positive inclusive human development benefits may be traceable to several factors documented in the underlying literature, inter alia: efficiency in household management (Al Surikhi, 2012); enhancement of health services (Kliner et al., 2013); women empowerment (Maurer, 2008; Ojo et al., 2012); promotion of financial inclusion (Singh, 2012, p. 466; Kirui et al. 2013, p. 141); improvement of household business opportunities (Ondiege, 2010, p. 11; Mishra \& Bisht, 2013, p. 505); elimination of demandand supply-side constraints as well as agricultural wastes (Muto \& Yamano, 2009; Aker \& Fafchamps, 2010) and bridging of the rural-urban divide (Qiang et al., 2011, pp. 14-26; Chan \& Jia, 2011, pp. 3-5). The present inquiry has complemented this strand of literature by establishing that enhanced governance standards would potentially improve the inclusive human development benefits of mobile phones currently being enjoyed by the sampled countries in SSA.

\section{Concluding implications}

This study has assessed the synergy effects of governance in mobile phone penetration for inclusive human development in Sub-Saharan Africa (SSA) with data for the period 20002012 by employing a battery of interactive estimation techniques, namely: Fixed effects (FE), Generalised Method of Moments (GMM) and Tobit regressions. Concepts of political (voice $\&$ accountability and political stability/no violence), economic (government effectiveness and regulation quality) and institutional (corruption-control and rule of law) governance have been employed. The following findings have been established.

First, the previously apparent positive correlation between mobile phones and inclusive development in Africa can be extended to a positive effect in SSA. As a policy implication, in the post-2015 development agenda, the mobile revolution remains a relevant means to inclusive development and pro-poor growth in the sub-region. Second, whereas political governance is overwhelmingly not significant across estimated models, average effects from economic governance on inclusive development are higher relative to institutional governance. As a policy implication, in increasing order, political governance, institutional governance and economic governance are positively associated with inclusive human development.

Third, on the synergy effects from interactions between the mobile phone and governance variables, whereas none are apparent in FE regressions, there are significant 
synergy effects in the GMM and Tobit estimations, notably, from: (i) regulation quality in the former and (ii) political stability, voice \& accountability and rule of law in the latter. As a policy implication, governance can consolidate the gains of inclusive development from mobile phones. However, the corresponding low net effects further imply that governance standards need to be improved in order to accelerate the underlying inclusive gains for the post-2015 development agenda. Fourth, there is consistent evidence of convergence in inclusive human development. The implication for this convergence is that countries with lower levels of inclusive human development in SSA are catching-up their counterparts with higher levels of inclusive development. Future studies within the scope of this inquiry would improve the extant literature by decomposing the: (i) sub-region into fundamental characteristics of African development and (ii) inclusive human development index into its constituents in order to assess how the established findings are reflected in the fundamentals and constituents respectively. 


\section{Appendices}

\begin{tabular}{|c|c|c|c|}
\hline Variables & Signs & Definitions & Sources \\
\hline $\begin{array}{l}\text { Inclusive } \\
\text { development }\end{array}$ & IHDI & Inequality Adjusted Human Development Index & UNDP \\
\hline Mobile Phone & Mobile & Mobile phone subscriptions (per 100 people) & WDI \\
\hline $\begin{array}{l}\text { Political } \\
\text { Stability }\end{array}$ & Pols & $\begin{array}{l}\text { "Political stability/no violence (estimate): measured as the perceptions } \\
\text { of the likelihood that the government will be destabilized or } \\
\text { overthrown by unconstitutional and violent means, including domestic } \\
\text { violence and terrorism". }\end{array}$ & WDI \\
\hline $\begin{array}{l}\text { Voice \& } \\
\text { Accountability }\end{array}$ & VA & $\begin{array}{l}\text { "Voice and accountability (estimate): measures the extent to which a } \\
\text { country's citizens are able to participate in selecting their government } \\
\text { and to enjoy freedom of expression, freedom of association and a free } \\
\text { media" }\end{array}$ & WDI \\
\hline $\begin{array}{l}\text { Government } \\
\text { Effectiveness }\end{array}$ & GE & $\begin{array}{l}\text { "Government effectiveness (estimate): measures the quality of public } \\
\text { services, the quality and degree of independence from political } \\
\text { pressures of the civil service, the quality of policy formulation and } \\
\text { implementation, and the credibility of governments' commitments to } \\
\text { such policies". }\end{array}$ & WDI \\
\hline $\begin{array}{l}\text { Regulation } \\
\text { Quality }\end{array}$ & RQ & $\begin{array}{l}\text { "Regulation quality (estimate): measured as the ability of the } \\
\text { government to formulate and implement sound policies and } \\
\text { regulations that permit and promote private sector development". }\end{array}$ & WDI \\
\hline $\begin{array}{l}\text { Corruption- } \\
\text { Control }\end{array}$ & $\mathrm{CC}$ & $\begin{array}{l}\text { "Control of corruption (estimate): captures perceptions of the extent to } \\
\text { which public power is exercised for private gain, including both petty } \\
\text { and grand forms of corruption, as well as 'capture' of the state by } \\
\text { elites and private interests" }\end{array}$ & WDI \\
\hline Rule of Law & RL & $\begin{array}{l}\text { "Rule of law (estimate): captures perceptions of the extent to which } \\
\text { agents have confidence in and abide by the rules of society and in } \\
\text { particular the quality of contract enforcement, property rights, the } \\
\text { police, the courts, as well as the likelihood of crime and violence" }\end{array}$ & WDI \\
\hline GDP per capita & GDPpcg & GDP per Capita growth rate & \\
\hline Private Credit & Credit & $\begin{array}{l}\text { Private credit by deposit banks and other financial institutions (\% of } \\
\text { GDP) }\end{array}$ & WDI \\
\hline Remittance & Remit & Remittance inflows (\% of GDP) & WDI \\
\hline $\begin{array}{l}\text { Foreign } \\
\text { investment }\end{array}$ & FDI & Foreign Direct Investment net inflows ( $\%$ of GDP) & WDI \\
\hline
\end{tabular}

UNDP: United Nations Development Program. WDI: World Development Indicators. GDP: Gross Domestic Product. 


\section{Appendix 2: Summary statistics}

\begin{tabular}{llllll}
\hline & Mean & SD & Min & Max & Obs \\
\cline { 2 - 6 } Inequality Adj. Human Development & 0.721 & 3.505 & 0.129 & 0.768 & 485 \\
Mobile Phone Penetration & 23.379 & 28.004 & 0.000 & 147.202 & 572 \\
Political Stability & -0.543 & 0.956 & -3.323 & 1.192 & 578 \\
Voice \& Accountability & -0.646 & 0.737 & -2.233 & 0.990 & 578 \\
Government Effectiveness & -0.771 & 0.620 & -2.450 & 0.934 & 577 \\
Regulation Quality & -0.715 & 0.644 & -2.665 & 0.983 & 578 \\
Corruption-Control & -0.642 & 0.591 & -1.924 & 1.249 & 579 \\
Rule of Law & -0.741 & 0.662 & -2.668 & 1.056 & 578 \\
GDP per Capita growth & 2.198 & 5.987 & -49.761 & 58.363 & 608 \\
Private Domestic Credit & 18.551 & 22.472 & 0.550 & 149.78 & 507 \\
Remittances & 3.977 & 8.031 & 0.000 & 64.100 & 434 \\
Net Foreign Direct Investment Inflows & 5.332 & 8.737 & -6.043 & 91.007 & 603
\end{tabular}

SD: Standard deviation. Min: Minimum. Max: Maximum. Obs: Observations. Adj: Adjusted.

Appendix 3: Correlation Matrix (Uniform sample size: 330)

\begin{tabular}{|c|c|c|c|c|c|c|c|c|c|c|c|c|}
\hline \multirow[b]{2}{*}{ PolS } & \multicolumn{3}{|c|}{ Governance Variables } & \multirow[b]{2}{*}{$\mathrm{CC}$} & \multirow[b]{2}{*}{ RL } & \multicolumn{4}{|c|}{ Control Variables } & \multirow{2}{*}{$\begin{array}{l}\text { Ind. } \\
\text { Vble } \\
\text { Mobile }\end{array}$} & \multirow{2}{*}{$\begin{array}{l}\text { Dep. } \\
\text { Vble } \\
\text { IHDI }\end{array}$} & \multirow[b]{3}{*}{$\mathrm{D} 1 \mathrm{C}$} \\
\hline & VA & GE & RQ & & & GDPpcg & Credit & Remit & FDI & & & \\
\hline \multirow[t]{12}{*}{1.000} & 0.688 & 0.653 & 0.625 & 0.692 & 0.777 & -0.011 & 0.279 & 0.032 & -0.018 & 0.310 & 0.411 & \\
\hline & 1.000 & 0.774 & 0.734 & 0.683 & 0.810 & 0.113 & 0.452 & 0.042 & -0.010 & 0.318 & 0.361 & VA \\
\hline & & 1.000 & 0.877 & 0.836 & 0.897 & 0.118 & 0.543 & 0.020 & -0.152 & 0.389 & 0.584 & GE \\
\hline & & & 1.000 & 0.799 & 0.856 & -0.0001 & 0.532 & -0.076 & -0.192 & 0.363 & 0.512 & RQ \\
\hline & & & & 1.000 & 0.851 & 0.053 & 0.469 & -0.196 & -0.104 & 0.373 & 0.519 & $\mathrm{CC}$ \\
\hline & & & & & 1.000 & 0.070 & 0.471 & 0.079 & -0.084 & 0.345 & 0.507 & RL \\
\hline & & & & & & 1.000 & 0.029 & 0.026 & 0.172 & 0.043 & 0.077 & GDPpcg \\
\hline & & & & & & & 1.000 & -0.095 & -0.082 & 0.511 & 0.536 & Credit \\
\hline & & & & & & & & 1.000 & 0.122 & -0.056 & -0.043 & Remit \\
\hline & & & & & & & & & 1.000 & 0.075 & -0.026 & FDI \\
\hline & & & & & & & & & & 1.000 & 0.634 & Mobile \\
\hline & & & & & & & & & & & 1.000 & IHDI \\
\hline
\end{tabular}

PolS: Political Stability. VA: Voice \& Accountability. GE: Government Effectiveness. RQ: Regulation Quality. CC: Corruption-Control. RL: Rule of Law. GDPpcg: GDP per capita growth rate. Credit: Private domestic credit. Remit: Remittances. FDI: Foreign Direct Investment. Mobile: Mobile Phone Penetration. IHDI: Inequality Adjusted Human Development Index. Ind. Vble: Independent Variable. Dep. Vble: Dependent Variable.

\section{References}

Aker, J. C., \& Fafchamps, M., (2010). "How Does Mobile Phone Coverage Affect Farm-Gate Prices? Evidence from West Africa", Department of Economics and the Fletcher School, Tufts University. 
Al Surikhi, H. F., (2012). "Knowledge and Financial Management in Households: An Examination of Married Women's Perspectives in Chadbourn, North Carolina", Capstone Collection, Paper No. 2489.

Anand, R., Mishra, S., \& Spatafora, N., (2012), "Structural Transformation and the Sophistication of Production," IMF Working Paper No. 12/59, Washington.

Andrés, R. A, \& Asongu, S. A., (2013). "Fighting Software Piracy: Which Governance Tools Matter in Africa?", Journal of Business Ethics 118(3), pp. 667-682

Andrés, R. A, Asongu, S. A., Amavilah, V. H., (2014). "The Impact of Formal Institutions on Knowledge Economy", Journal of the Knowledge Economy:

http://link.springer.com/article/10.1007\%2Fs13132-013-0174-3 (Accessed : 31/19/2015).

Anyanwu, J., \& Erhijakpor, A., (2014). "Does Oil Wealth Affect Democracy in Africa?"African Development Review, 26 (1), pp. 15-37.

Arellano, M., \& Bond, S., (1991), "Some tests of specification for panel data: Monte Carlo evidence and an application to employment equations" The Review of Economic Studies, 58, pp. 277-297.

Arellano, M., \& Bover, O., (1995), "Another look at the instrumental variable estimation of errorcomponents models", Journal of Econometrics, 68, pp. 29-52.

Ariss, R. T., (2010), "On the Implications of Market Power in Banking: Evidence from Developing Countries", Journal of Banking and Finance, 34, pp. 765-775.

Asongu, S. A., (2013a). "How has mobile phone penetration stimulated financial development in Africa", Journal of African Business, 14(1), pp. 7-18.

Asongu, S. A., (2013b). "Harmonizing IPRs on Software Piracy: Empirics of Trajectories in Africa", Journal of Business Ethics, 118(1), pp. 45-60.

Asongu, S. A., (2014a). "Mobile banking and mobile phone penetration: which is more propoor in Africa?", African Governance and Development Institute Working Paper No. 13/033, Yaoundé.

Asongu, S. A., (2014b). "African development: beyond income convergence", South African Journal of Economics, 83(3), pp. 334-353.

Asongu, S. A., (2015a). "Conditional Determinants of Mobile Phones Penetration and Mobile Banking in Sub-Saharan Africa", Journal of the Knowledge Economy. http://link.springer.com/article/10.1007\%2Fs13132-015-0322-Z

Asongu, S. A., (2015b). "The impact of mobile phone penetration on African inequality", International Journal of Social Economics, 42(8), pp. 706 - 716

Asongu, S. A., (2015c). "Reinventing foreign aid for inclusive and sustainable development: Kuznets, Piketty and the great policy reversal", Journal of Economic Surveys: 
http://onlinelibrary.wiley.com/doi/10.1111/joes.12109/abstract

Asongu, S. A., (2015d). "Determinants of Growth in Fast Developing Countries: Evidence from Bundling and Unbundling Institutions”, Politics \& Policy, 44(1), pp. 97-134

Asongu, S. A., \& De Moor, L., (2015). "Recent advances in finance for inclusive development: a survey", African Governance and Development Institute Working Paper No. 15/005, Yaoundé.

Asongu, S. A., \& De Moor, L., (2016). "Financial globalisation dynamic thresholds for financial development: evidence from Africa", European Journal of Development Research, doi:10.1057/ejdr.2016.10.

Asongu, S. A., \& Kodila-Tedika, O., (2015). “Is Poverty in the African DNA (Gene)?”, African Governance and Development Institute Working Paper No. 15/011, Yaoundé.

Asongu, S. A., \& Kodila-Tedika, O., (2016). "Fighting African Conflicts and Crimes: Which Governance Tools Matter?” International Journal of Social Economics, 43(5), pp. 466-485.

Asongu, S. A., \& Nwachukwu, J., (2015). "Revolution empirics: predicting the Arab Spring" Empirical Economics: http://link.springer.com/article/10.1007/s00181-015-1013-0

Asongu, S. A., \& Nwachukwu, J., (2016). "The Role of Lifelong Learning in Political Stability and Non-violence: Evidence from Africa" Journal of Economic Studies, 43(1), pp. 141-164.

Asongu, S. A., Efobi, U., \& Beecroft, I., (2015). "Inclusive Human Development in Pre-Crisis Times of Globalisation-Driven Debts", African Development Review, 27(4), pp. 428-442.

Baltagi, B. H., (2008). "Forecasting with panel data", Journal of Forecasting, 27(2), pp. 153173.

Bauer, S., De Niet, J., Timman, R., \& Kordy, H., (2010). "Enhancement of care through selfmonitoring and tailored feedback via text messaging and their use in the treatment of childhood overweight", Patient Education and Counseling, 79 (2010), pp. 315-319.

Blundell, R., \& Bond, S., (1998). "Initial conditions and moment restrictions in dynamic panel data models” Journal of Econometrics, 87(1), pp. 115-143.

Bond, S., Hoeffler, A., \& Tample, J. (2001) “GMM Estimation of Empirical Growth Models", University of Oxford.

Brambor, T., Clark, W. M., and Golder, M., (2006). "Understanding Interaction Models:Improving Empirical Analyses”, Political Analysis, 14 (1), pp. 63-82.

Chan, A., \& Jia, T., (2011). "The Role of Mobile Banking in Facilitating Rural Finance: Reducing Inequality in Financial Services between Urban and Rural Areas", Accenture Banking Services, http://www.accenture.com/SiteCollectionDocuments/PDF/PoV-MobileBanking-051611-EN.pdf (Accessed: 17/03/2015). 
Coccorese, P., \& Pellecchia, A., (2010), “Testing the 'Quiet Life' Hypothesis in the Italian Banking Industry”, Economic Notes by Banca dei Paschi di Siena SpA, 39(3), pp. 173-202.

Da Costa, T. M. Salomão, P. L., Martha, A. S., Pisa, I. T., \& Sigulem, D., (2010). "The impact of short message service text messages sent as appointment reminders to patients' cell phones at outpatient clinics in São Paulo, Brazil", International Journal of Medical Informatics, 79 (2010), pp. 65-70.

Dixit, A., (2009). "Governance Institutions and Economic Activity", American Economic Review, 99(1), pp. 5-24.

E-agriculture (2012). "Using ICT to enable Agricultural Innovation Systems for Smallholders", e-source book, ICT In Agriculture, Connecting Small Holders to Knowledge, Networks and Institutions, (Forum 4, September 2012). http://www.fao.org/docrep/018/ar130e/ar130e.pdf (Accessed: 18/03/2015).

Efobi, U., (2015). "Politicians' Attributes and Institutional Quality in Africa: A Focus on Corruption", Journal of Economic Issues, 49(3), pp. 787-813.

Fonchingong, C., (2014). "Firming Up Institutional Policy for Deprived Elderly in Cameroon”, Politics \& Policy, 42(6), pp. 948-980.

Fosu, A., (2013a), "Growth of African Economies: Productivity, Policy Syndromes and the Importance of Institutions" Journal of African Economies, 22(4): 523-551.

Fosu, A., (2013b). "Growth of African Economies: Productivity, Policy Syndromes and the Importance of Institutions" Journal of African Economies 22(4): 523-551.

Fosu, A., (2015a). Growth and Institutions in African Development, First edited by Augustin K. Fosu, , Routledge Studies in Development Economics: New York

Fosu, A., (2015b). Growth and institutions in African Development, in Growth and Institutions in African Development, First edited by Augustin K. Fosu, 2015, Chapter 1, pp. 1-17, Routledge Studies in Development Economics: New York.

Fosu, A. K., (2015c). "Growth, Inequality and Poverty in Sub-Saharan Africa: Recent Progress in a Global Context”, Oxford Development Studies, 43(1), pp. 44-59.

Fukuyama, F., (2013). “What is Governance?”, Governance, 26(3), pp. 347-368.

Fung, M. K., (2009). "Financial development and economic growth: Convergence or divergence?", Journal of International Money and Finance, 28, pp. 56-67.

Gani, A., (2011). "Governance and Growth in Developing Countries", Journal of Economic Issues, 45(1), pp. 19-40.

Hoffman, J. A., Cunningham, J. R., Suleh, A. J., Sundsmo, A., Dekker, D., Vago, F., \& Munly, K., (2010). "Mobile Direct Observation Treatment for Tuberculosis Patients A 
Technical Feasibility Pilot Using Mobile Phones in Nairobi, Kenya", American Journal of Preventive Medicine, 39(1), pp. 78-80.

Jonathan, D., \& Camilo, T. (2008). Mobile banking and economic development: Linking adoption, impact and use. Asian Journal of Communication, 18(4), 318-322.

Kaufmann, D., Kraay, A., \& Mastruzzi, M., (2007a). "Growth and Governance: A Reply”, Journal of Politics, 69(2), pp. 555-562.

Kaufmann, D., Kraay, A., \& Mastruzzi, M., (2007b). "Growth and Governance: A Rejoinder", Journal of Politics, 69(2), pp. 570-572.

Kaufmann, D., Kraay, A \& Mastruzzi, M., (2010). "The worldwide governance indicators: Methodology and analytical Issues". World Bank Policy Research Working Paper No 5430, Washington.

Kirui, O. K., Okello, J. J., Nyikal, R. A., \& Njiraini, G. W., (2013). "Impact of Mobile PhoneBased Money Transfer Services in Agriculture: Evidence from Kenya", Quaterly Journal of International Agriculture, 52(2), pp. 141-162.

Kliner, M., Knight, A., Mamvura, C., Wright, J., \& Walley, J., (2013). "Using no-cost mobile phone reminders to improve attendance for HIV test results: a pilot study in rural Swaziland", Infectious Diseases of poverty, 2(12), pp. 1-7.

Koetter, M., Kolari, J. W., \& Spierduk, L., (2008), "Efficient Competition ? Testing the 'Quiet Life' of U.S Banks with Adjusted Lerner Indices", Proceedings of the $44^{\text {th }}$ 'Bank Structure and Competition' Conference, Federal Reserve Bank of Chicago.

Kramon, E., (2009). "Vote Buying and Turnout in Kenya's 2002 Elections”, University of California, Los Angeles, http://www.sscnet.ucla.edu/polisci/wgape/papers/17_Kramon.pdf (Accessed: 23/08/2015).

Kumbhakar, S. C., \& Lovell, C. A. K., (2000), Stochastic Frontier Analysis, Cambridge MA: Cambridge University Press.

Kuoa, Y-F., \& Yub, C-W., (2006). “ 3G telecommunication operators' challenges and roles: A perspective of mobile commerce value chain", Technovation, 26(12), pp. 1347-1356.

Kumar, S., \& Zahn, C., (2003). "Mobile communications: evolution and impact on business operations", Technovation, 23(6), pp. 515-520.

Kurtz, M., \& Schrank, A., (2007a). "Growth and Governance: Models, Measures, and Mechanisms", Journal of Politics, 69(2), pp. 538-554.

Kurtz, M., \& Schrank, A., (2007b). "Growth and Governance: A Defense", Journal of Politics, 69(2), pp. 563-569.

Jin, J., \& von Zedtwitz, M., (2008). "Technological capability development in China's mobile phone industry”, Technovation, 28(6), pp. 327-334. 
Lee, M., Kim, K \& Cho, Y., (2010). "A study on the relationship between technology diffusion and new product diffusion", Technological Forecasting and Social Change, 77(5), 796-802.

Love, I., \& Zicchino, L., (2006). "Financial Development and Dynamic Investment Behaviour: Evidence from Panel VAR" .The Quarterly Review of Economics and Finance, 46(2), pp. 190-210

Maurer, B. (2008, May). Retail electronic payments systems for value transfers in the developing world. Department of Anthropology, University of California.

McDonald, J., (2009), "Using Least Squares and Tobit in Second Stage DEA Efficiency Analyses”, European Journal of Operational Research, 197, pp. 792-798.

Mishra, V., \& Bisht, S. S., (2013). "Mobile banking in a developing economy: A customercentric model for policy formulation”, Telecommunications Policy, 37, pp. 503-514.

Mishra, S., Gable, S. L., \& Anand, R., (2011), "Service Export Sophsitication and Economic Growth," World Bank Policy Working Paper No. 5606, Washington.

Mlachila, M., Tapsoba, R., \& Tapsoba, S. J. A., (2014). “A Quality of Growth Index for Developing Countries: A Proposal”, IMF Working Paper No. 14/172, Washington.

Mpogole, H., Usanga, H., \& Tedre, M., (2008). "Mobile phones and poverty alleviation: a survey study in rural Tanzania", Proceedings of M4D 2008, Karlstad University, Sweden, pp. $62-72$.

Muto, M., \& Yamano, T., (2009). "The Impact of Mobile Phone Coverage Expansion on Market Participation: Panel Data Evidence from Uganda", World Development, 37(12), pp. 1887-1896.

Ojo, A., Janowski, T., \& Awotwi, J., (2012). "Enabling development through governance and mobile technology", Government Information Quarterly, 30 (2013), pp. S32-S45.

Oluwatobi, S., Efobi, U.R., Olurinola, O.I., Alege, P. (2015), "Innovation in Africa: Why Institutions Matter”, South African Journal of Economics, 83(3), pp. 390-410.

Ondiege, P., (2013). "Fostering financial inclusion with mobile banking", African

Development Bank.

http://www.proparco.fr/webdav/site/proparco/shared/PORTAILS/Secteur_prive_developpeme nt/PDF/SPD16/SPD16_Peter_Ondiege_UK.pdf (Accessed: 03/02/2015).

Ondiege, P., (2010). "Mobile Banking in Africa: Taking the Bank to the People", Africa Economic Brief, 1(8), pp. 1-16.

Penard, T., Poussing, N., Yebe, G. Z., \& Ella, P. N., (2012). "Comparing the Determinants of Internet and Cell Phone Use in Africa: Evidence from Gabon ", Communications \& Strategies, 86, pp. 65-83. 
Qiang, C. Z., Kuek, S. C., Dymond, A., \& Esselaar, S., (2011). "Mobile Applications for Agricultural and Rural Development", ICT Sector Unit, World Bank http://siteresources.worldbank.org/INFORMATIONANDCOMMUNICATIONANDTECHN OLOGIES/Resources/MobileApplications_for_ARD.pdf (Accessed: 17/03/2015).

Roodman, D., (2009a). "A Note on the Theme of Too Many Instruments", Oxford Bulletin of Economics and Statistics, 71(1), pp. 135-158.

Roodman, D., (2009b). "How to do xtabond2: An introduction to difference and system GMM in Stata”, Stata Journal, 9(1), pp. 86-136.

Seneviratne, D., \& Sun, Y., (2013), "Infrastructure and Income Distribution in ASEAN-5: What are the Links?" IMF Working Paper No. 13/41, Washington.

Singh, A. B., (2012). "Mobile banking based money order for India Post: Feasible model and assessing demand potential", Procedia - Social and Behavioral Sciences, 37, pp. 466-481.

Ssozi, J., \& Amlani, S., (2015) "The Effectiveness of Health Expenditure on the Proximate and Ultimate Goals of Healthcare in Sub-Saharan Africa", Economics Department, Hankamer School of Business, Baylor University.

Ssozi, J., \& Asongu, S. A., (2015). " The Effects of Remittances on Output per Worker in Sub-Saharan Africa: A Production Function Approach", South African Journal of Economics, http://onlinelibrary.wiley.com/doi/10.1111/saje.12100/abstract

Tchamyou, V. S., (2015). "The role of knowledge economy in African business", Journal of the Knowledge Economy: Forthcoming.

Tusalem, R. F., (2015), "State Regulation of Religion and the Quality of Governance", Politics \& Policy, 43(1), pp. 94-141.

Warren, M., (2007). "The digital vicious cycle: links between social disadvantage and digital exclusion in rural areas". Telecommunications Policy, 31(6-7), pp. 374-388.

West, D. M., (2013). "Improving Health Care through Mobile Medical Devices and Sensors", Centre for Technology and Innovation at Brookings, http://www.brookings.edu/ /media/research/files/papers/2013/10/22\%20mobile\%20medical \%20devices\%20west/west_mobile\%20medical\%20devices_v06 (Accessed: 19/03/2015).

World Bank (2015). "World Development Indicators", World Bank Publications http://www.gopa.de/fr/news/world-bank-release-world-development-indicators-2015

(Accessed: 25/04/2015).

Yerrabati, S., \& Hawkes, D., (2015). "Economic Governance and Economic Growth in South and East Asia \& Pacific Region: Evidence from Systematic Literature Reviews and Metaanalysis". Advances in Economics and Business, 3 , pp. 1 - 21. 